\title{
Students' Mathematical Thinking Ability in Solving Geometry Problems based on Cognitive Style
}

\author{
Noor Fajriah, Rizki Amalia \\ Mathematics Education Department \\ Universitas Lambung Mangkurat \\ Banjarmasin, Indonesia \\ n.fajriah@unlam.ac.id
}

\begin{abstract}
Students are expected to have higher order thinking skills, yet they were rarely given problems to practice those skills during the primary, junior high and senior high schools. In regard to solve the problems, everyone has different characteristics in compiling and processing information as well as experiences that they are owned, this is known as cognitive style. The purpose of this study was to determine students' mathematical thinking ability and the influence of cognitive style on mathematical thinking ability to solve geometry problems. This study employed descriptive method by involving 29 students who took geometry courses as the subjects. Mean score and linear regression analysis were used to analyze the research data. The results showed that students' mathematical thinking ability in solving geometry problems were in the qualification grade $\mathrm{C}^{+}$and there was a significant influence of cognitive style on students' mathematical thinking ability.
\end{abstract}

\section{Keywords-Ccognitive style, Mathematical thinking}

\section{INTRODUCTION}

Man is a creature of thought; therefore, there is not anyone who never experiences the stages of thinking. Thinking itself is processing information that has been received to respond or process something. In teaching and learning activities, students experience the process of thinking where the knowledge has been obtained will be more meaningful. Ibrahim and Nur [1] state that thinking is the ability to analyze, criticize, and reach conclusions based on inference or careful consideration. In addition, Marpaung [1] states that thinking is an activity that starts from finding information (from outside or student themselves), processing, storing and recalling information from students' memories. Based on some of these notions, thinking is a complex process in which the process begins with discovering, processing, and drawing conclusions.

The mathematics according to Johnson and Rising [2] is one of the subjects taught in formal education. Mathematics is taught gradually from concrete to abstract and continuously, so it needs special thinking skills termed mathematical thinking. Dewanto [3] states that the ability of high-level mathematical thinking is a capacity above the information provided. This ability is with a critical attitude to evaluate, has metacognitive awareness and has problem-solving skills. Stein and Lane [4] reveals that high-level mathematical thinking skills use complex, non-algorithmic thinking to solve an unpredictable problem and using different approaches to existing tasks or practice examples.

Based on some of the above statements, high-level mathematical thinking is one of the stages of thinking that cannot be separated from everyday life and each student is directed to have such a high-level thinking. As revealed by Dahlan [5], a high-level thinking example makes someone think critically when he/she gets data or information. This person will make the right and correct conclusions as well as see the contradiction, consistency or irregularities in the information.

In fact, practicing high-level mathematical thinking skills still becomes a problem. Students at the elementary, junior and senior high schools are rarely given the problems that train the high-level mathematical thinking skills. These students should have trained on the first semester for high-level mathematical thinking use.

Thompson [4] states that using Bloom's taxonomy is one of the alternatives used by lecturers to conduct an assessment of high-order thinking skills. Krathwohl [6] states that one of the indicators to measure the ability of high-level mathematical thinking includes the ability to analyze. Suherman and Kusumah [7] argue that analysis is an ability to break down or break a problem into smaller parts (components) and be able to understand the relationships between the parts.

With regard to solving problems, of course, each person has different characteristics, so have his/her own preferred way of composing what he sees, memorizes and thinks about. Thus, giving rise to ways of behaving, accepting, judging, thinking, and processing information from the problem becomes different too. Interpersonal differences in how to organize and process information and experiences are known as cognitive styles [8].

According to Slameto [8], cognitive style is an important variable that affects the choices of someone in the academic field, the continuation of academic development, how to learn and how to interact in the classroom. Its influence covers almost all human activities related to understanding, social functions and functions among people. One cognitive style that has been studied extensively is the so-called "Field independent" (FI) and "Field dependent" (FD). This cognitive style has been studied extensively. Desmita [9] states that the cognitive style of FD and FI is a type of cognitive style that 
reflects the way a person's analysis in interacting with his/her environment. Individuals with FD style tend to accept a pattern as a whole. They are difficult to focus on one aspect in one situation, or analyze patterns into different parts. In contrast, the individual with the FI style receives more separate parts of the overall pattern and analyzes the patterns into its components.

A student with FD cognitive style, finds difficulty in processing, but easily perceives when information is manipulated according to the context. He/she will be able to separate the stimuli in context, but his/her perceptions are weak when there is a change of context. Meanwhile, students with FI cognitive style tend to use internal factors as direction in processing information. They do the tasks in a row and feel efficient working on their own.

Slameto [8] also states that in certain subjects from various studies conducted showed that students with cognitive style FI prefer fields that require analytical skills such as mathematics, physics, biology, engineering and mechanical activities, while those who Cognitive-style FDs tend to choose areas that involve interpersonal relationships such as social sciences, persuasive activities, literature, and trade management.

As a result, the purpose of this research is to determine the students mathematical thinking ability in solving geometry problems based on cognitive style and to know the influence of cognitive style to students' mathematical thinking ability in solving geometry problems.

\section{METHOD}

The method used in this research was descriptive method. The subjects were the $1^{\text {st }}$ semester students in Mathematics Education FKIP Universitas Lambung Mangkurat, 2016-2017 academic year in a number of 29 students. The data were collected through test. Data analysis technique for the test of the mathematical thinking ability and cognitive style in this study was descriptive statistic consisting of average, percentage and simple linear regression analysis.

\section{RESULT AND DISCUSSION}

The results of cognitive style test showed that there were 17 students or $58,62 \%$ in FD category and students who were on FI category were 12 students $(41,38 \%)$. In the other words, more than $50 \%$ of the students of mathematics education program on geometry course had FD cognitive style. This is somewhat contrary to the opinion of (2010) that FI cognitive person prefers fields that require analytical skills such as mathematics, physics, biology, engineering and mechanical activities, whereas cognitive FD tend to choose areas that involve Interpersonal relationships such as social sciences, persuasive activities, literature, and trade management. This situation becomes a challenge for lecturers in the study program to provide motivation to students to continue to learn and practice to improve their ability.

Teachers can help more than $50 \%$ of students with FD cognitive style who tend to respond a global problem focused on the environment as a whole. This is because their perceptions are easily influenced by the environmental manipulation. This is done by utilizing a conducive campus environment and a representative reading room that will affect students to be better. The average score of students' mathematical thinking ability was 67,59 with $\mathrm{C}^{+}$grade. The distribution of qualification of the value of mathematics education students who took the geometry course can be seen in the following table.

TABLE I. Distribution OF MATHEMATICAL Thinking ABILITY QUALIFICATION

\begin{tabular}{|l|l|l|l|l|}
\hline No. & Qualification & $\begin{array}{l}\text { Frequency } \\
(\mathbf{f})\end{array}$ & $\begin{array}{l}\text { Percentage } \\
(\boldsymbol{\%})\end{array}$ & Description \\
\hline 1 & A & 12 & 41,38 & Pass \\
\hline 2 & A- & 0 & 0 & Pass \\
\hline 3 & B + & 0 & 0 & Pass \\
\hline 4 & B & 4 & 13,79 & Pass \\
\hline 5 & B- & 0 & 0 & Pass \\
\hline 6 & C + & 0 & 0 & Pass \\
\hline 7 & C & 4 & 13,79 & Pass \\
\hline 8 & D & 2 & 6,90 & Not Pass \\
\hline 9 & D & 5 & 17,24 & Not Pass \\
\hline 10 & E & 2 & 6,90 & Not Pass \\
\hline Total & & 29 & 100,00 & \\
\hline
\end{tabular}

Based on Table I above, there were $31,03 \%$ students who met the pass criteria with the mean that still has not reached $75 \%$ of the number of students. It appears that the mathematical thinking ability of the mathematics education students who took the geometry course is not satisfactory when it is viewed from the average and the criteria of students who passed. Students who took the geometry course on the early semester are not accustomed yet to solve different geometry problems with exercises. Another thing is it is possibly the geometry problems which were solved is the ability of analysis where based on opinions Bloom [10] it is one of the most abstract higher order thinking skills. Stein and Lane [4] reveal that high-level mathematical thinking capabilities use complex, non-algorithmic thinking to solve an unpredictable problem and use different approaches to existing tasks or exercise samples so that not all students are able to complete this type of problem.

The students mathematical thinking ability based on the cognitive style can be seen in Table II.

TABLE II. DISTRIBUTION QUALIFICATION OF STUDENTS Mathematical THINKING ABILITY BASEd on COGNITIVE STYLE

\begin{tabular}{|c|c|c|c|c|c|c|}
\hline \multirow[t]{2}{*}{ No } & \multirow[t]{2}{*}{ Qualification } & \multicolumn{2}{|c|}{$\begin{array}{l}\text { Frequency } \\
\text { (f) }\end{array}$} & \multicolumn{2}{|c|}{$\begin{array}{l}\text { Percentage } \\
(\%)\end{array}$} & \multirow[t]{2}{*}{ Description } \\
\hline & & $F I$ & $F D$ & $F I$ & $F D$ & \\
\hline 1 & $\mathrm{~A}$ & 7 & 5 & 58,3 & 29,4 & Pass \\
\hline 2 & $\mathrm{~B}$ & 2 & 2 & 16,7 & 11,8 & Pass \\
\hline 3 & $\mathrm{C}$ & 1 & 3 & 8,3 & 17,6 & Pass \\
\hline 4 & $\mathrm{D}+$ & 2 & 0 & 16,7 & 0,0 & Not Pass \\
\hline 5 & $\mathrm{D}$ & 0 & 5 & 0,0 & 29,4 & Not Pass \\
\hline 6 & $E$ & 0 & 2 & 0,0 & 11,8 & Not Pass \\
\hline \multicolumn{2}{|c|}{ Total } & 12 & 17 & 100,0 & $\begin{array}{l}100, \\
0\end{array}$ & \\
\hline
\end{tabular}

Table II shows that $16 \%$ of students who have FI cognitive style did not fulfill the pass criterion while students who have 
cognitive style FD who did not meet pass criterion were $41,2 \%$. This means that more than $75 \%$ FI students have met the pass criterion, but FD students did not meet such this big percentage. This is in accordance with the opinion of Slameto [8] who states that in certain subjects from various studies conducted showed that students with FI cognitive style prefer fields that require analytical skills while those with FD cognitive-style tend to choose areas involving interpersonal relationships. Therefore, FI cognitive style students ability to think mathematically is better than FD cognitive style students.

To know the effect of cognitive style on students' mathematical thinking ability, the data were analyzed using SPSS software. The value of the relationship between the ability of mathematical thinking and cognitive style was 0,438 . This value of the relationship indicated that the relationship between mathematical thinking ability and cognitive style is sufficient. The value of $\mathrm{R}$ square or determination value obtained that the percentage of the influence of independent variables (cognitive style) to the dependent variable (cognitive style) was $19,1 \%$, while the rest was influenced by other variables. The regression model that can be used to predict the ability of mathematical thinking with cognitive style is $\mathrm{Y}=41,879+2,958 \mathrm{x}$.

\section{CONCLUSION AND SUGGESTION}

Based on the results and discussion above, it can be concluded that students mathematics education mathematical thinking ability who took geometry course in the odd semester of 2016-2017 academic year is in qualification of $\mathrm{C}+$ grade and there is significant effect between cognitive style and students mathematical ability.
Preferably in the process of studying, the lecturers of mathematics education department provide more analysis and cognitive style exercises as a consideration in maximizing the students thigher order thinking ability.

\section{REFERENCES}

[1] Darminto, B. P, Studi Perbandingan Model-Model Pembelajaran Berbasis Komputer dalam Peningkatan Kemampuan Berpikir Matematis Tingkat Tinggi Calon Guru di Perguruan Tinggi Muhammadiyah. Disertasi PPS UPI Bandung: tidak diterbitkan. 2008.

[2] Tim MKPBM. Strategi Pembelajaran Matematika Kontemporer. Bandung: Jurusan Pendidikan Matematika FPMIPA UPI. 2001

[3] Dewanto, S. Meningkatkan Kemampuan Berpikir Matematik Tingkat Tinggi melalui Pembelajaran dengan Pendekatan Induktif-Deduktif. Tesis PPS UPI Bandung: tidak diterbitkan. 2004.

[4] Thompson, T. "mathematics teachers' interpretation of higher-order thinking in bloom's taxonomy". International Electronic Journal of Mathematics Education. 3, (2), pp. 96-109. 2008.

[5] Dahlan, J. A. Analisis Kurikulum Matematika. Jakarta: Universitas Terbuka, 2011.

[6] Krathwohl, D. R. A Revision of Bloom's Taxonomy: an overview. Theory Into Practice. 41 (4), pp. 212-218. 2002.

[7] Suherman, E. dan Kusumah, Y. S. Evaluasi Pendidikan Matematika. Bandung: Wijayakusumah, 1990.

[8] Slameto. Belajar dan Faktor-Faktor Yang Mempengaruhinya. Jakarta: RinekaCipta, , 2010.

[9] Desmita. Psikologi Perkembangan Peserta Didik. Bandung: PT Remaja Rosda karya, 2009.

[10] Herman, T. "Pembelajaran Matematika Berbasis Masalah Untuk Meningkatkan Kemampuan Berpikir Matematik Tingkat Tinggi Siswa SLTP”. Artikel PPS Pendidikan Matematika UPI Bandung. 2002. 